Murmurations:

Journal of

Transfórmative

Systemic

Practice

\title{
Pandemic Disease and Systems Theory: An Ecological View
}

\author{
Ray Becvar and Stan Amaladas
}

\section{Volume 3 \\ Issue 1 \\ Autumn 2020}

Keywords:

Systems theory, ecosystems thinking, guests, hosts, being human, coronavirus, Covid-19

\section{Citation Link}

\begin{abstract}
The fundamental problem that we raise and address in this paper is the problem of understanding our relationship with our afflictions in ways that are uniquely shaped by such afflictions. We capture our need to shifting our attention from our dominant Western epistemology to systems thinking. In this article, we argue that systems theory and thinking
\end{abstract}

- reminds us of the pathologies of epistemology that may preclude learning from our relationship with Covid-19.

- offers us a way to examine the relationship between an uninvited guest like Covid-19 guests and hosts (human beings) particularly in the light of Rumi's formulation of being human, namely, as being a "guest house". While we may never get to a place where we invite Covid-19 into our lives, we can at least respect the fact that it will exist in our lives, as afflictions do, and with this awareness we can begin to find ways to co-exist with it, in the same way that we must do with all other creatures and nature on our only home - Mother Earth.

- opens us to telling a story about our afflictions in ways that are uniquely shaped by such afflictions. In this regard the authors examine several human responses (stories) to Covid-19 within the context of our system that continues to change and evolve.

- uncovers the need to recover from our state of addiction to a state of sobriety. The state of sobriety returns us to an awareness that we cannot just do one thing because each movement or perturbation necessarily resonates throughout the system.

- allows us to shift to an ecological rather than a solely political or economic view of Homo Sapiens. This ecological shift moves us into a moral/ethical realm (we use them interchangeably here) whereby humankind learns to abide by another law. It is a law that is itself punctuated by the distinction between control and restraint. The punctuation of this distinction enables us to become more aware of our attempts to establish a unilateral control over 
that which is multilateral. These attempts will not only fail, but they would also create different, and perhaps more serious problems. This development of another law to abide by, suggests that we surrender ourselves to being governed by the law of restraint.

In this paper, we focus on the relationship between the pandemic disease called Covid-19 and people, through the conceptual lens of systems theory. Both philosophically and pragmatically, our paper is about Bateson's (1979) concept of epistemology. Bateson presents Occidental epistemology as a method of thinking that leads to a mindset in which man exerts an autocratic rule over all cybernetic systems. In exerting his autocratic rule, "man" changes the environment to suit him and in doing so he unbalances the natural cybernetic combination of competition and mutual dependency and "it is that combination that is the important thing to consider" (Bateson, 1979, p. 438). It is this concept of combination that guides our thinking in this paper.

Part of the challenge with our "Western" way of thinking is that it provides us with a method of thinking that sees people as independent of and separated from the contexts of which they are necessarily a part. Implicit in this assumption is that there is a set of values of what is "supposed to be" or "not supposed to be". Furthermore, we tend to live our lives without conscious awareness that our "belief system" is only a belief system. And, as Becvar (2017) argued, we "tend to cling to these beliefs literally for dear life or at least for dear sanity" (p. 3), because they are our grounding, our securing, and our certainty. Consequently, they are "not easily open to reflective questioning, and are less easily changed even when they do not serve the individual's intended purposes" (Bartlett, 1983, p. 25).

Systems theory provides an alternative world view that may help us to more than survive the current pandemic, to prepare us for future challenges, and for our continued life on this planet. At base, systems theory is about relationships, interconnections, and interdependencies. Thomas (1978), for example, offers a useful technical definition of a system: “ . . . a system is a structure of interacting, intercommunicating components that, as a group, act or operate individually and jointly to achieve a common goal through the concerted activity of the individual parts" (p. 12). This is, of course a completely satisfactory definition of the natural conditions of earth, except maybe for the last part about a common goal.

The concept of goal necessarily reflects humans espousing diverse and often times contradictory values that prescribe specific purposes and outcomes. Systems theory is a useful perspective in that, consistent within itself, it would have us see reciprocal rather than linear causation as we explore the relationship between people and Covid-19. Indeed, from a systems perspective the concepts of cause and control are inconsistent with the concept of relationship. Systems theory also reminds us that it is we observers who punctuate components of a whole that is never actually divided. We believe that systems theory provides a better lens through which we can develop a meaningful understanding of our relationship with the virus that is now a part of our lives.

The virus is rather like an unwanted/uninvited guest, and yet it is a part of the family of creatures that co-habit this planet. In another sense, while we may not have consciously invited this guest, in living or not living the way we have lived, we have created a context that opened the door for this creature/virus called Covid-19 to take center stage in our lives. But we get ahead of ourselves. We 
begin our story with the belief that a systems-thinking perspective may offer a better means to develop an understanding of how to live well with this uninvited creature/guest. Humans as species seem to need stories to understand and live our lives. The way things really are will ever elude us, but our stories may offer us a meaningful coherence. So, what story can we tell in response to our question: what would it mean to live well with this uninvited guest/creature/virus? But before we answer our question, allow us to share who we are.

\section{Who Are We?}

As scholar-practitioners in the fields of sociology and leadership studies (Amaladas) and family therapy (Becvar), we share a principled relationship to ecosystemic thinking. Following Gregory Bateson and Mary Catherine Bateson (1987), this perspective challenges us to look for

i. patterns that connect socially constructed relationships,

ii. within a particular context, and

iii. it orients to unveiling how we know what we know.

Unlike the dominant scientific paradigm that separates the combination of both the observer from the observed, ecosystemic thinking theorises that we cannot be in any system and not be a part of it (Bateson, 1979). Ecosystemic thinking orients to the participation of observers within that which they observe (system/world) and their participation in enabling their realities to be what they are. This higher-order consciousness is consistent with second-order cybernetics (Bateson, 1979), namely that observers are aware that they are and cannot not be a part of a totally interconnected universe.

At the same time, we both share a deep passion for the place of stories in our lives and in the capacity of self and others to transcend storied conditions that limit growth and change. It is this passion that brings us together to inquire into our shared questions: What would it mean to live well with this uninvited guest/creature/virus called Covid-19? What does it mean to live well with our afflictions?

\section{Being Human is a Guest House}

As a way of responding to our questions, allow us to appeal to Jalāl ad-Dīn Rumi, a $13^{\text {th }}$ century a Persian poet, and in particular, his poem, "The Guest House". The opening lines of his poem reads as follows:

This being human is a guest house.

Every morning a new arrival.

A joy, a depression, a meanness,

some momentary awareness comes

As an unexpected visitor.

Indeed, globally, we are in the middle of a "new arrival" as an "unexpected visitor", called Covid-19, and it is heartless and indifferent, at least as it is viewed from a human perspective. Its worldwide negative effects are felt in over many hundred thousand deaths within a space of seven months, in 
the havoc it has created in politics, economics, medical professions, and education, in the closing of schools and universities, in human experiences of panic, fear, anger, and all that we have come to accept as routine every day behaviours. We are particularly troubled by this new arrival's/guest's indifference to its hosts. The concept of indifference suggests it not only has a mind of its own, but it also has a purpose and its purpose is perverse. It knows no boundaries and it is unsympathetic to whom it attacks.

Consequently, while it may be "natural" for hosts in their guest houses to do all that they can to eradicate or evict this "new arrival", Rumi continues his poem by offering a strikingly different choice. He calls on his readers to "Welcome and entertain them all!" And if this runs counter intuitive of the meanness of Covid-19's presence, Rumi adds more: "treat each guest honourably - Even if they're a crowd of sorrows who violently sweep your house empty of its furniture..." because, as he opined, "he may be clearing you out for some new delight". In concluding his poem, he further calls on his readers to "Be grateful for whoever comes because each has been sent as a guide from beyond".

The questions that we raise and address in this paper are: If being human is a guest house, then how do we, as hosts, entertain, be grateful, and treat this uninvited guest honourably especially since it has created significant levels of dis-ease among its unsuspecting hosts? What new delight might there be in store for us? While a vaccine might be developed to treat the virus, and we will be glad when this occurs, our memory of its presence will always be with those of us who survive this virus, and the questions that we raise in this paper will continue to haunt our human existence.

Our questions suggest that inasmuch as Covid-19, as an affliction, has become a part of our human history, it raises the problem of understanding our relationship with our afflictions, in ways that are uniquely co-influenced (not caused or determined) by both our understanding and our understanding of our understanding of what it means to be afflicted. Ecosystemic thinking suggests that this problem will always persist, and it will not end even when a cure is found. To raise the problem in this way is to move away from a linear cause-effect relationship with our afflictions where causes and effects move in a uni-direction. An ecosystemic perspective moves us to orient towards a recursive way of thinking where effects come back to the cause. Figure 1 captures the essence of this relationship.

Figure 1: Recursive relationship between observer and system

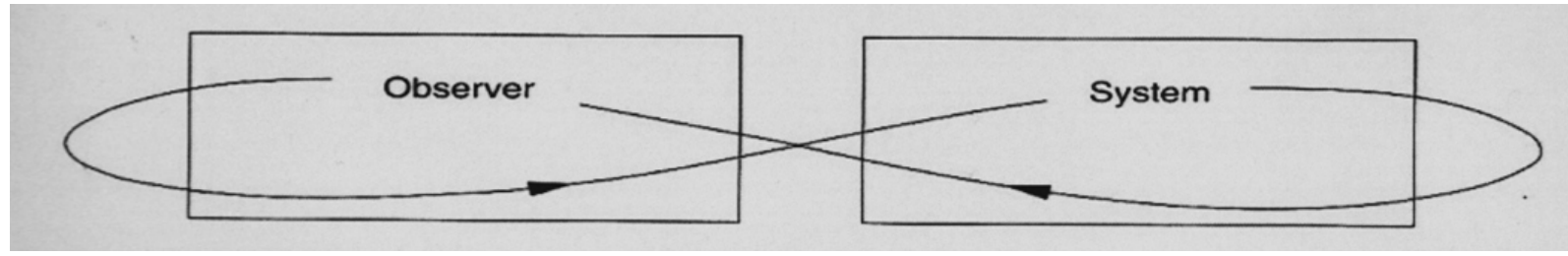

Becvar, 2017

We acknowledge that any understanding that we humans might develop is but an understanding - to satisfy our need to find one. Said differently, we need a story because, as Isak Dinesen noted, "all sorrows can be borne if you put them into a story or tell a story about them" (as cited in Arendt, 1983, p. 104). Adding to "Isak" Dinesen thoughts, a male pseudonym name which Karen Christentze Dinesen adopted to half show and half hide her authorship because of "her firm conviction that it was not very 
becoming for a woman to be an author" (Arendt, 1983, p. 95), Arendt (1983), suggests that we need a story because it "reveals the meaning of what otherwise would remain an unbearable sequence of sheer happenings" (p. 104).

Subsequently, as we are in the company of an unwelcomed guest/visitor, allow us to at least entertain its presence by asking: what story (stories) can we tell from its uninvited visit? As one of us was recently blessed with a grandchild, imagine a grandfather telling their grandson a story about Covid19. Perhaps the beginning of his story could be something like this: "Once upon a time, human beings claimed that they did not consciously invite a guest called Covid-19. But as the story goes, they may well have created the conditions that can be experienced as an invitation. And a strange part of this story, my dear grandson, is that human beings started taking an interest in an uninvited guest that had absolutely no interest in them". To not tell a story about that which is now a part of our story (history), would essentially mean that we at best ignore, or at worst, deny its presence. And for Arendt (1983), it would mean that we simply experience its uninvited presence as yet another unbearable sheer happening. Let us continue our story then, by "entertaining" human responses to Covid-19 as a way of developing an understanding of what it means to live with and learn from its uninvited visit by orienting to is as if, as Rumi recommends, it is a "guide from beyond". (Yes, this too is a part of our story).

\section{More Than a Technical Problem}

If the suffering of our Covid-19 affliction is seen only as a technical problem, then the suffering of hosts can be alleviated through financial and economic compensations, and social practices like wearing of masks, washing of hands, sanitising, physical and social distancing. Without denying the need for these kinds of support and safe practices, we would suggest that while these do offer a level of temporary relief from economic pain and fear, it cannot take away the life of suffering our afflictions. The life of suffering still remains untouched by technical solutions to a more complex problem. Another way of expressing this is that technical solutions, although necessary in times of Covid-19, will not enable us to entertain the idea that Covid-19 has become part of our history and story or the opportunity to understand the complex problem of what it means to suffer our own afflictions. At best, technical solutions can only offer us a way of coping with the negative effects of this disease by offering temporary financial relief or temporary solutions through safe practices. At the same time, while in this middle of this pandemic, in the midst of this "uninvited visitor" we do hear a common refrain from the doorsteps of politicians (some at least), front-line workers, and those in the social media: "We are all in this together". Allow us to shift our attention to this common refrain.

\section{We Are All In This Together}

As logical as this refrain sounds, some will be tempted to suggest that "all" are not equally in danger of becoming hosts to the virus. In the United States, for example, the poor, the health-care workers, and people of colour are more likely to be inflicted than others. Similarly, some people around the globe are more likely to be hosts than others. There is an injustice in our togetherness that reflects class and caste differences. This politicised response, however, would distract us from answering the questions that we raise for ourselves. As a way of answering our questions, we need to ask: what more 
can this refrain affirm? The best that this refrain, "we are all in this together", affirms is that the affliction of "all" in the midst of Covid-19, is "our" problem and to be a guest-house is essentially to take collective responsibility for responding thoughtfully to suffering the injustice of our own afflictions. It is to entertain the idea that this uninvited guest, has in effect, raised our consciousness to pay attention to the suffering of all hosts as a collective responsibility (as a societal problem) that must be addressed.

\section{On Guests and Hosts}

In speaking of guests and hosts, systems theory reminds us that we have punctuated a distinction. The idea of guests, by virtue of being a guest, presuppose the presence of a host. The idea of hosts, by virtue of being a host, presuppose the presence of a guest. Guests and hosts are two concepts that belong together. Allow us to reference the anthropologist and system's thinker, Bateson's (Gregory Bateson \& Mary Catherine Bateson, 1987) experiment where he demonstrated the complementarity of seemingly opposite thoughts through his imaginary conversation (Metalogue) with his daughter (pp. 35-36):

Daughter: I did an experiment once.

Father: Yes?

Daughter: I wanted to find out if I could think two thoughts at the same time. So, I thought "It's summer" and I thought "it's winter". And then I tried to think the two thoughts together. Father: Yes?

Daughter: But I found I wasn't having two thoughts. I was only having one thought about two thoughts.

In this experiment, Bateson raises our consciousness to a higher level of thinking (meta-logue or metaconsciousness) that affirms that we cannot think of "summer" without thinking of "winter". In a similar way, the ecology of systems thinking invites us to think and orient thoughtfully to the relationship between guests and hosts. Hence, insofar as it takes "two to know one", what he is saying is that it is the relationship and the connectedness of two thoughts that completes the distinction (Flemons, 1991).

\section{Ecology of Systems Thinking}

Within the context of Covid-19, the ecology of systems thinking moves us to understand the relationship between an unwanted guest and unsuspecting hosts in ways that allow us to move beyond the tyranny and oppressiveness of our afflictions - not to extinguish its trace, or submit to its oppressive power, or to be demoralised by what afflicts us - but to understand how to integrate our afflictions, and suffering what we did not ask for, into our own lives. It is an understanding that orients to this uninvited guest as "a guide from beyond" and not as a "thing" out-there imposing itself on us. This suggests that we need to maintain a collective focus and discipline to orienting thoughtfully to the presence of Covid-19 in ways that are not distracted, for example, by reactions like blaming which may be driven by concerns like who in particular is responsible for its presence. Within the context of an American response to Covid-19, blaming, we would suggest, politicises our afflictions. In saying this, we do not mean to ignore the causes of this pandemic disease for the sake of preventing further 
outbreaks of this kind. We are, however, interested in the human story of blaming within the context of both Covid-19 and from within the lens of systems theory.

Senge (2006), an organisational learning theorist, affirms that there is "in each of us a propensity to find someone or something outside ourselves to blame when things go wrong" (p. 19). He formulates this propensity to blame as a way of thinking that rests secure with the idea that the "enemy is out there" (p. 19). Accepting responsibility (not blaming) for Senge, however, "comes from seeing how we contribute to our own problems" (2006, p. 21), namely, by orienting to an enemy that is "in-here", and within ourselves. This human punctuation of "in-here" and "out-there", and the separation of both concepts, however, distracts us from seeing how the two are interconnected. It attracts us instead to perpetuate the division or separation between "in-here" and "out-there", or for that matter "hosts" and "guests". Blaming distracts us from orienting to our afflictions as a problem that is neither "in-here" or "out-there", but in the relation between the "in here" and "out-there".

One real consequence of blaming is that it distracts us from orienting thoughtfully to diseases as a part of the cycle of living and dying, and it distracts us from thinking about our relationship to both living and dying. Indeed, living and dying is our human condition. From a non-indigenous American context, for Lewis (1978), a "biological watcher", as he refers to himself, part of the problem is that

The long habit of living....has become an addiction: we are hooked on living; the tenacity of its grip on us, and ours on it, grows in intensity. We cannot think of giving it up, even when living loses its zest - even when we have lost the zest for zest. (pp. 45-46)

Part of the problem, as Lewis (1978) ascertains, is that in hiding our thoughts about dying, and in selfcongratulating ourselves "with all the marvelous ways in which we seem now to lead nature around by the nose", (p. 45), we, as mortal beings, can ignore and avoid this central fact of life. Human beings can pretend to believe that they can become a little smarter and expect cures for all diseases. In so doing, they become more addicted to convincing themselves as being in control as they exert more control over nature. We, as human beings, tend to become full of ourselves. As we "conquer" each new infectious disease, we can, for example, be seduced by large pharmaceutical companies into believing that the era of infectious disease is over or that we can live longer. We can be seduced into thinking that we can control nature, and that we are in control.

It is here that we need to pay heed to the voice of systems theory. If we are a part of nature, the challenge is: how do we control ourselves as the part that may well have created the conditions for the evolution and migration of this uninvited guest to us as hosts? Perhaps it may be appropriate to first understand how human beings came to believe in their ability to "control" everything around themselves, including nature.

\section{The Industrialised Model}

Over the course of human history, and especially since the age of Industrialisation, humans began to punctuate themselves as separate from and of a higher-order species than nature. Recall, for instance, Marx's (1856/1978), a political theorist, reflections of the surprise and drastic results of 
industrialisation:

On the one hand, there have started into life, industrial and scientific forces, which no epoch of human history had ever suspected. On the other hand, there exist symptoms of decay, far surpassing the horrors of the latter times of the Roman Empire. (p. 577)

The life of industrialisation is a life that attempts to control. Like Protagoras, industrialised human beings believe that they are the "measure of all things" (as cited in Plato, Cratylus, 386) And, as Marx, noted, "no earlier century had even a presentiment that such productive forces slumbered in the lap of social labour" (1978, p. 477). Today, we continue to exploit and desecrate the limited natural resources available to us on Earth as if they are unlimited. Curiously, for Marx (1856/1978), human attempts to control nature, is not driven by arrogance but rather by their total addiction their own success.

The success of the "bourgeoisie", as Marx noted, is a result of the productive capacity to create "massive and more colossal productive powers than have all preceding generations together" (p. 477). It was indeed the addicted success of a total "subjection of nature's forces to man" (Marx, 1978, p. 577), that moved the industrialised man to "embellish" themselves with, as the sociologist Weber (1958) noted, a "sort of convulsive sense of self-importance" (p. 182). In the face of our socially addicted conditions, Marx (1856/1978) makes a passionate plea: it is time to sober up, and "face with sober senses his real conditions of life, and his real relations with his kind" (p. 476). For Marx, individuals who are addicted/intoxicated are incapable of understanding the real conditions of their lives because they are too busy being intoxicated.

Whereas intoxicated people punctuate themselves as separate from and independent of nature, the sober person, understands the real condition that we are part of nature. Indeed, where in this world can we be and not be a part of it? According to Bateson (1979), the belief that total control is possible is a pathology of Occidental epistemology. It seduces humankind to continue exerting an autocratic control over all interrelated systems. The presence of this unwanted visitor called Covid-19, however, makes real the reality that human beings are not in control and that they cannot escape diseases or death because these are parts of nature's being.

Conceptually, the addicted person's concept of "the novel coronavirus as a disease" is meaningless when viewed in context of relationships. In truth, we, as human beings, live only because other creatures and plants live and die. At the same time, creatures and plants live because they have other "hosts" to feed on. Their "hosts" die so that they can live. All species are gifts and are sacred. All species should be our gift to our children. But the style of life we have evolved for ourselves is deadly for other species, and we continue to poison the world for future generations by our behaviour as consumers.

\section{"It is like I Pressed the Reset Button"}

Within the context of the addicted life-style as noted above, the appearance and presence of this uninvited visitor, has however, triggered the development of another story. For example, in a virtual gathering of friends, through the technology of Zoom, several shared their experiences. 
- "I realise that I did not have to rush in to work or get mega-stressed contending with the traffic. Yet, I got my work done."

- "I realised that my calendar was simply too full of things "to do". My "to do list" was so long that it did not allow me time for myself or my family. My life was simply too complicated."

- "You know it is like I pressed the "reset" button."

There is much to be unpacked in the "realisations" expressed above. First, when Covid-19 entered our lives, we have become more aware of the way we lived our lives previously. There is an affirmation that life is simple. Ironically, in our attempts to simplify our lives, we have done much to complicate our lives. Perhaps the addiction of our "busy-ness" is our signature of being "hooked on living". Second, it appears as if this pandemic disease has not only raised our awareness of what is important in our lives, but it also has reminded us of (resetting us to) the flaw in the design of our own lives. In our age of technology, and in particular with the use of our Android or I-Phones, when things go "wrong", or where a technical "flaw" is discovered, there is always the possibility of "righting the wrong" by pressing the "reset" key. This returns the phone to its previously constructed "factory settings". Returning to Rumi's poem, could these realisations be Covid-19's way of violently sweeping its "guest's house" empty of its "furniture" - could it be its way of resetting our priorities - for the sake of clearing us out for some new delight?

From a systems theory perspective, perhaps the crisis of this pandemic disease is clearing us out to become aware of the "flaws" in the systems that govern our relationship with disease. Perhaps it is clearing our minds (furniture) out of our state of addiction/intoxication to a state of being sober? Hegel (1970), a $20^{\text {th }}$ century philosopher, offers us a way of thinking about what it means to be afflicted by a disease. "In disease", he notes, "the individual is entangled with an external (non-organic) power and is held fast in one of its particular organs in opposition to the unity of its vitality" (pp. 440-441). The force of disease is such that it can "flaw-fully" hold an individual fast or be fixated on its "external non-organic power", to the point of opposition to a unified vitality. By seducing us to the point of making paramount the survival of our bodies - as if that is all there is to being in the world - disease and singular attempts to cure us from disease, distracts us from purposefully orienting to the relationship among the "external non-organic power" and a unified vitality of life which sees disease as a part of living. Consequently, in the presence of disease, we are seduced to rely heavily on medical professionals who specialise in freeing the individual from suffering this external non-organic power. In this sense, prescribing pills is medicine's way of controlling and eradicating the negative effects of this external non-organic power. Consuming the prescribed pills becomes the patient's way of colluding and conforming to this medical story. This is one way through which patients act on their belief that they can regain control of their own bodies and survive the disease. Ironically, while taking the prescribed pill is one way of returning the diseased individual back to a previous state of health, the third leading cause of death in the United States is connected to medical errors (Sipherd, 2018).

The "realisations" that we alluded to earlier, however, offer a different story. In the attempt to "reset" their lives, it appears as if this disease called Covid-19 has moved some to alter their priorities differently. They have chosen not to be determined by the foreign power of Covid-19-the unwanted guest/visitor. The have chosen instead, to orient to what is important or meaningful in their lives. This shift affirms that there is more to life than survival. It affirms that individuals are able to respond to 
the "unity of its vitality", by not giving away their power to being determined by this disease and hence not allowing this disease to take possession of their thoughtful response to living a unified life - with zest and vitality, and especially when they have lost the zest for zest. In fact, the realisations noted above suggest that this disease offers us the opportunity (possibility) to clear our thoughts (furniture) to the point where we can now make a coordinated effort to reclaim that which is important and meaningful to living a good life. Indeed, they have pushed their "reset" buttons.

\section{Not a Return to the Good Old Days}

We would further suggest that this resetting, cannot and does not mean that we begin to return to the way things were before the glitch that necessitated the reset button. It is not a return to the "good old days" or to a previous understanding of "normality" because the context has changed. It is not to return to more of the same which will only produce more of the same. It is in effect a re-turning to a forgotten state of being, and to a sober relationship with one's real conditions. It is as if Covid-19 is offering the addicted person the possibility of "recovery". It is here that we are reminded of Heraclitus, the "weeping philosopher's" fragment, as it was noted by Socrates: "Heraclitus is supposed to say that all things are in motion and nothing at rest; he compares them to the stream of a river and says that you cannot go into the same water twice" (Plato, Cratylus, 402). Insofar as all things are in motion and nothing at rest, Heraclitus could be heard as saying that we cannot return to our stream of our consciousness (river) twice, because our consciousness (river) has changed (constantly flowing) and because our experience (intellectual context) has changed. Because both the river (consciousness) and the individual (experience) are in a state of systemic flux, we cannot "go into the same water twice". We have changed and our intellectual climate has changed. At the same time, viruses and bacteria also evolve and mutate to fit changing circumstances. Indeed, our attempts to control them may have stimulated their need to evolve and mutate in order to survive. While they will ever be with us, and while viruses, bacteria, and creatures are a part of what makes our lives possible, it is ironic in that our singular attempts to control them are also what makes them possible to evolve and mutate. The inability to press the "reset" button would, in effect, mean that all one can do in the middle disease, is to be overwhelmed by its presence and be subjugated to its power. Pressing the "reset" button, on the other hand, is one way of detaching oneself from its overwhelming power. It is one way of reconnecting ourselves to inquiring into our relationship with that which afflicts us as a problem that is worth examining. The inability to do so would mean that we surrender ourselves to the influence of the disturbing power of the non-organic. In so doing, this would result in humans surrendering themselves to simply suffering the effects of this disease and rely more on medicine to cure them from those effects. By implication it excludes alternative means to boost our immune systems.

The inability to press the "reset" button also moves one to a state of panic - namely where the hearts of individuals become pervaded by the fear of death, or, in the language of Hegel, by the fear of the extinction of their vitality. It would only affirm that one's highest aspiration is the absence of fear. Perhaps this is it what it means to be truly dis-eased. The ability to press the "reset" button, on the other hand, affirms that the sober awareness of one's own mortality - because we are all finite beings - can move individuals to orient to what is important and meaningfully live with a "unified vitality". While there is the realisation that we will all die from our diseases and that our human organs will over time deteriorate, breakdown, and die, there is also the realisation that pressing the "reset" 
button offers us the possibility of living with our afflictions in ways that are not determined by our afflictions. It offers us an opportunity to inquire into and develop a healthy relationship with our afflictions (our diseases). The inability to do so, would in fact, condemn us to living our lives as victims of our afflictions. As victims, we surrender ourselves to only feeling the negative effects of the external force of disease. In giving away one's own power to the negative effects of disease, we create higher levels of anxiety and asking for a pill and yet more pills, is one way of freeing oneself from anxiety. This experience of our afflictions continues to be perpetuated by our "culture" which defines the failure to be free from anxiety as an anomaly.

Pressing the "reset" button, would also move us away from a focus on self ("I") to a focus on the collective ("We") - namely to an appreciation of our parts and roles in the generation of these afflictions. It enables us the opportunity to mindfully "hold" our breathing between inhaling and exhaling. In this "holding environment", we give ourselves the gift to pause and recursively reflect on our constitution of our world. This brings us to a conversation of the individual (observer) in relation to what is being observed.

\section{The Observer and the Observed}

Unlike first order cybernetics (the cybernetics of the observed system), which separates the observed and the observer, pressing the "reset" button moves us to the realm of the cybernetics of observing systems (second order cybernetics, cybernetics of cybernetics) which includes both the observed and the observer. The latter makes a fundamental epistemological shift from considering oneself as an independent and detached observer who watches the world go by, to considering oneself as a participant in the drama of mutual interaction, of the give and take in the circularity of human relations (von Foerster, 1990). Second order cybernetics asserts that we cannot be in the world and not be a part of it. It also asserts that while we cannot not be a part of it, in our attempts to "know" we again assume a position outside the system. As finite beings without a God's eye view of the world, our human fate is to be both a part of and outside of a system simultaneously. Covid-19 may indeed be clearing us out of the furniture of first-order cybernetics. It may be preparing us for the new delight that comes from second-order cybernetics.

Once we accept the fact that we are a part of nature, our attempts to correct "flaws" would take a different turn. We might just see that the "flaws" we attempt to correct are "flaws" because of our attempts to correct them. Thus, instead of attempting to seek to bring things under our control, we might seek ways to participate in this world in ways that complement and respect the rights of other creatures who have equal rights to be in this world, while acknowledging that our attempted solutions may well have precipitated the Covid-19 problem. For example, the clearing of the habitats of wild animals or killing them for food, are bringing us more into contact with those animals and their "diseases". Consequently, one hypothesis in relation to Covid-19 that needs to be addressed is our relationship that that which we kill for food. The belief that we are the only creatures endowed with conscious awareness fosters the belief that we have the right to attempt unilateral control over our relationship with nature. Attempts at unilateral control over that which is multilateral will fail. It licenses us, to use Rumi's language, to not treat our uninvited guest/visitor honourably. 


\section{Shift to an Ecological View of our World}

If we are to learn from this from Covid-19, our new arrival, we need to develop a more ecological (egalitarian) relationship within all that exist in our world - with other human beings, with other creatures, and with nature. The natural resources of this world necessary for sustaining life are not unlimited. Lopez (2019) writes, "Australian philosopher Val Plumwood has written that humanities task now is to resituate non-humans in the ethical and humans in the ecological". Lopez continues,

Having an ecological - - rather than a solely political or economic - - view of Homo sapiens and knowing that the physical environment exerts a selective pressure on the human genome lead to a straightforward observation: to care for the environment is to care for the self. To run roughshod over the environment is to subscribe to the belief that humans are free to remain indifferent to their physical environments, that natural selection doesn't apply to them (p. 263).

Arguably, Lopez's observation reverses our previously assumed ways of thinking about the natural world which gave us permission to exploit nature without restraint. As Browne (2007) notes, "ecological thinking, expression, and action all involve the willingness to limit our use of power and to check our intellectual arrogance, to leave some room for wonder and for the world" (p. 147). To check our intellectual arrogance is to (a) check our addiction to control, (b) check our attitude of indifference to our own physical environments, and (c) check our convulsive sense of self-importance. It open us to the possibility of developing a moral/ethical and ecological relationship with both humans and nonhumans (creatures included). It opens us to care for both the environment and for ourselves. For Lopez (1986), it opens us up to restraining ourselves from running roughshod over the environment. And it is precisely the lack of restraint that troubled him and made him uncomfortable as he walked across the tundra, "in a region of chirping birds, distant caribou, and redoubtable lemmings" (p. 38), which he shares in his book Artic Dreams.

Because mankind can circumvent evolutionary law, it is incumbent upon him...to develop another law to abide by if he wishes to survive, to not outstrip his food base. He must learn restraint. He must derive some other, wiser way of behaving in the land...Not because he must...but because herein is the accomplishment of the wisdom that for centuries he has aspired to. Having taken on his own destiny, he must now think with critical intelligence about where to defer (pp. 38-39).

We notice that Lopez punctuates a distinction between control and restraint. Systems theory, as we noted earlier, would say that we cannot talk or think of one without the other. Whereas humankind can circumvent evolutionary law, their arrogance and addiction seduces them to believe that they can survive by outstripping their food base (life of control). To "play" with Marx's (1843/1978) understanding of sobriety, soberness, on the other hand, enables mankind to think with critical intelligence and with a "knowing" that accepting a life of restraint would necessitate paying attention to how we choose to participate with the world, for the sake of the world, and for everything in it, including caring for the self - again, for where can we be in the world and not be a part of it.

To shift to an ecological view of the world, then, is to shift to an ecological way of living that includes the critical intelligence of restraint, namely knowing "about where to defer". It is because we have the technology and the artificial intelligence to control, "use-up" and consume just about everything in 
our world, the wisdom of critical intelligence moves us instead to think about our moral and immoral relationship with our world (people; natural resources; creatures). To shift to an ecological view of the world and to an egalitarian relationship with all that exist in our world, is to shift to a moral/ethical relationship with all that exists with us in this world. In this we cannot be neutral or indifferent. To shift to a thinking "about where to defer" - to a life of restraint - is a moral undertaking. It is only in this way that we can treat uninvited guests honourably. One startling discovery is that if we remain complacent in relation to our previous ways of trying to control our lives, our relationships, and our environment because of our individualised addiction to greed and over-consumption, destruction and pollution, quick fixes, and bad nutrition, then we are doomed to fail.

\section{Conclusion}

Perhaps the language of "conclusion", is misleading. We would like to "conclude" our thoughts on the relationship between this pandemic disease called Covid-19 and people, by suggesting that we need to begin anew. The fundamental problem that we raised and addressed in this paper, is the problem of understanding our relationship with our afflictions in ways that are uniquely influenced by our understanding of such afflictions. We captured where we need to begin anew through our conversation about shifting our attention from an occidental epistemology to systems theory. In our paper we argued that systems theory

(i) Reminds us of the pathologies of epistemology that may preclude learning from our relationship with Covid-19.

(ii) Offers us a way to examine the relationship between guests and hosts particularly in the light of Rumi's formulation of being human, namely, as being a "guest house". While we may never get to a place where we invite Covid-19 into our lives, we can at least respect the fact that it will exist in our lives, as afflictions do, and with this awareness we can begin to find ways to co-exist with it, in the same way that we must do with all other creatures and nature on our only home - Mother Earth.

(iii) Opens us to telling a story about our afflictions in ways that are uniquely shaped by such afflictions. In this regard we examined several human responses (stories) to Covid-19 within the context of our system that continues to change and evolve.

(iv) Uncovers the need to recover from our state of addiction to a state of sobriety. The state of sobriety returns us to an awareness that we cannot just do one thing because each movement or perturbation necessarily resonates throughout the system.

(v) Allows us to shift to an ecological rather than a solely political or economic view of Homo Sapiens. This ecological shift moves us into a moral/ethical realm (we use them interchangeably here) whereby humankind learns to abide by another law. It is a law that is itself punctuated by the distinction between control and restraint. The punctuation of this distinction enables us to become more aware of our attempts to establish a unilateral control over that which is multilateral These attempts will not only fail, but they would also create different, and perhaps more serious problems. This development of another law to abide by, suggests that we surrender ourselves to being governed by the law of restraint. 
Covid-19 and the desire to live our lives well, necessitates a shift to paying attention to a three-way relationship between Covid-19, people, and "another law to abide by" - the law of restraint. To abide by anything is to suggest that we accept and give ourselves over to that which governs us. It is a life of surrendering. It is to surrender oneself to being governed by the law of restraint rather than control. But what is curious about this surrendering, according to Lopez (1986), is that we surrender not because we must, "but because herein is the accomplishment of the wisdom that for centuries he has aspired to" (p. 39). It is in essence an accomplishment of the wisdom of our human aspiration to live wisely. Said differently, one critical lesson that the presence of our uninvited guest/visitor is teaching us, is that it is calling us to surrender to the wisdom to which we aspire because it is wise to do so.

\section{References}

Amaladas, Stan (2018). Intentional leadership: Getting to the heart of the matter. New York: Routledge.

Arendt, Hannah (1983). Isak Dinesen. In H. Arendt Men in Dark Times (pp. 95-109). New York: Harcourt Brace \& Company

Bartlett, Steven (1983). Conceptual therapy: An introduction to framework-relative epistemology.

St. Louis, MO: Crescere.

Bateson, Gregory (1979). Mind and nature: A necessary unity. New York: E.P. Dutton.

Bateson, Gregory \& Bateson, Mary Catherine (1987). Angels fear: Toward an epistemology of the sacred. New York: Macmillan Publishing Company.

Becvar, Raphael (2017). Sources of random and other essays. . The Marriage \& Family Therapy \& Systemic Studies Programs. University of Louisiana. Monroe, AL: Don D. Jackson Archive.

Becvar, Dorothy \& Becvar, Raphael (2013). Family therapy: A systemic integration ( $8^{\text {th }}$ edition). Boston, MA: Allyn and Bacon.

Browne, Neil (2007). The world in which we occur John Dewey, pragmatist ecology, and American ecological writing in the twentieth century. Tuscaloosa, AL: The University of Alabama Press.

Flemons, Douglas (1991). Completing distinctions. Boston, MA: Shambhala.

Hegel, Georg Wilhelm Friedrich (1970). Hegel's philosophy of nature. \# 374. Oxford, UK: Oxford University Press.

Lewis, Thomas (1978). Lives of a cell: Notes of a biology watcher. New York: Penguin Books.

Lopez, Barry (1986). Artic Dreams: Imagination and desire in a northern landscape. New York: Vintage Books.

Lopez, Barry (2019), Horizon. New York: Alfred A. Knopf.

Marx, Karl (1856/1978). Speech at the anniversary of the people's power. In R.C. Tucker (Ed.), The Marx-Engels Reader (pp. 577 - 578). New York: W. W. Norton \& Company, Inc.

Plato (1892/1937). Cratylus. In M.A. Jowett (Trans.), Dialogues of Plato (pp. 173-232). New York: Random House.

Rumi, Jalāl ad-Dīn (13 ${ }^{\text {th }}$ Century). The Guest House. Retrieved from http://www.sagemindfulness.com/blog/rumi-s-poem-the-guest-house 
Senge, Peter (2006). The fifth discipline. New York: Doubleday.

Von Foerster, Heinz (1970) Ethics and second-order cybernetics. Opening address for the International Conference, Systems and Family Therapy: Ethics, Epistemology, New Methods, held in Paris, France, October 4 th, 1990.

Weber, Max (1958). The protestant ethic and the spirit of capitalism. New York: Charles Scribner's Sons.

\section{Authors}

Stan Amaladas is Associate Professor at Baker College, Centre for Graduate Studies, Flint, MI, USA. E-mail: samala02@baker.edu

Ray Becvar is Retired Professor and Endowed Chair of Marital and Family Therapy at University of Louisiana, Monroe, USA.

\section{Citation}

Becvar, Ray \& Amaladas, Stan (2020). Pandemic Disease and Systems Theory: An Ecological View. Murmurations: Journal of Transformative Systemic Practice, 3, 1, 29-43. https://doi.org/10.28963/3.1.12 